\title{
SEASONAL PREVALENCE OF BOVINE TUBERCULOUS LESIONS IN CATTLE SLAUGHTERED IN YOLA ABATTOIRS
}

\author{
E. F. Ejeh ${ }^{1}$, I. F. Markus ${ }^{3}$, A. S. Ejeh ${ }^{2}$, J. A. Musa ${ }^{1}$, F. A. Lawan ${ }^{1}$, J. A. Ameh ${ }^{1}$, A. C. Kudi ${ }^{4}$ and \\ S. I. B. Cadmus ${ }^{5}$ \\ ${ }^{1}$ Department of Veterinary Microbiology and Parasitology, University of Maiduguri, Nigeria \\ ${ }^{2}$ Veterinary Teaching hospital, University of Agriculture, Makurdi, Nigeria \\ ${ }^{3}$ Minstry of Agriculture and Natural Development, Yola, Nigeria \\ ${ }^{4}$ Department of Veterinary Medicine, Ahmadu Bello University, Zaria, Nigeria \\ ${ }^{5}$ Department of Veterinary Public Health and Preventive Medicine, University of Ibadan, Nigeria
}

\begin{abstract}
Bovine tuberculosis is endemic in Nigeria. There is paucity of information on the prevalence of bovine tuberculous lesions in cattle slaughtered in Yola, Adamawa state. The annual prevalence and seasonal variation of bovine tuberculous lesions were assessed based on abattoir records of tuberculosis lesions from 2008 to 2012 . The overall prevalence of bovine tuberculosis lesions from 2008 to 2012 ranges from $8.68 \%$ (6.03 - 11.33) in 2008 to $10.33 \%$ (8.63 - 12.03\%) in 2012 with peak prevalence of $12.73 \%$ in 2011 . Types of lesions were not recorded systematically, however, lesions that were observed ranges from TB granuloma, TB abscesses with yellowish pus, caseous necrotic tubercles, multiple necrosis to focal granulomas. Annual prevalence of bovine tuberculosis lesions recorded in Yola abattoirs differ significantly $(p \leq 0.05)$. Prevalence of tuberculous lesions in Yola abattoirs was significantly influenced by season $(\mathrm{p}<0.05)$. Tuberculosis is endemic in cattle slaughtered in abattoirs meant for human consumption in Yola, therefore humans are at risk of acquiring zoonotic tuberculosis through consumption of contaminated meat.
\end{abstract}

Key words: Bovine tuberculosis, tuberculous lesions, Yola, prevalence, zoonotic

\section{INTRODUCTION}

Bovine tuberculosis (TB) is characterized by the development of granulomas (tubercles) where bacteria have localized. The granulomas are usually yellowish and either caseous, caseo-calcareous or calcified and often encapsulated (Rohonczy et al., 1996). Gross lesion were more in the thoracic cavity than in other regions of the body, the mediastinal lymph nodes are most commonly affected in TB confirmed animals while the tonsils are least affected (Liebana et al., 2008). In the lungs, the lesions are multiple coalescing foci of caseous necrosis surrounded by thin pale fibrous tissue capsule (tubercles) (Liebana et al., 2008). The lung parenchyma is almost entirely replaced by variably sized, coalescing, raised, pale nodules. Most of the lymph nodes are replaced by caseonecrotic debris with a laminated appearance reminiscent of caseous lymphadenitis (Rohonczy et al., 1996), in pigs the center of the lynph nodes is replaced by caseous, mineralized debris (Kaneene and Thoen, 2004), while the liver look pale and slightly raised granulomas are disseminated throughout all liver lobes (Anonymous, 2009). In bovine uterus, the endometrium contains numerous raised tubercles; the organism is also responsible for endometritis in women (Kumar et al., 2008). In some species such as deer, the lesions resemble abscesses rather than typical granuloma. Some tubercles are so microscopic that they cannot be seen with the necked eyes except with the aid of microscope in a sectioned tissue (Anonymous, 2009). Bovine tuberculosis is a disease caused mostly by the bacterium Mycobacterium bovis (Smith et al., 2006), Mycobacteriumcapriae (Brosch et al., 2002), Mycobacterium tuberculosis has been reported as the cause of tuberculosis in cattle (Cadmus et al., 2006) as well as other members of the MTbC (Cadmus et al., 2010; Jenkins et al., 2011). Mycobacterium bovis (M. bovis) can be transmitted by inhalation of aerosol, by ingestion or through break in the skin. The important of the routes varies between species (Anonymous, 2009). Venereal transmission through artificial insemination (AI) is possible (Wentink et al., 2000). Aerosol transmission occur usually where animals are in closed contact, thus animal density play a major factor in the transmission of M. bovis (Anonymous, 2013). Bovine tuberculosis is usually maintained in cattle populations (Anonymous, 2009), a few others can become reservoirs. Transmission of tuberculosis from cattle to human mostly occur through consumption of unpasteurized milk, closed contact with infected animal (Michel et al., 2010), air borne transmission (Vekemans et al., 1999; WHO, 2009) and consumption of infected meat (Anonymous, 2009). Tuberculosis in cattle is a disease of economic and zoonotic importance.

*Corresponding e-mail address: enenchefrancis@yahoo.com 


\section{E. F. Ejeh and others}

The disease is distributed worldwide, with African and Asian countries ranking highest in terms of disease burden (WHO, 2009). In developed countries, bovine tuberculosis had been controlled through test and slaughter method (Cosivi et al., 1998; Ayele et al., 2004; Theon et al., 2006; Amanfu et al., 2006; Smith et al., 2006), although bovine tuberculosis is still endemic in some industrialized countries like Australia and the Caribbean Island (Tweddle and Livingstone, 1994). The situation of bovine tuberculosis is completely different in Africa; with the emergence of HIV/AIDS, poverty and other debilitating diseases. The prevalence of bovine tuberculosis continue to increase in animals, these situation have potential impact on human health directly and threat to human livelihood by compromising sustainable food supply, income and social status (WHO, 2006).

Abattoir meat inspection provides useful insight into the prevalence of many animal diseases (FAO 1994; Cassidy et al., 2008) including TB, although by their nature, abattoirs' records are limited in detail in the data they provide (Aliyu et al., 2009), their importance cannot be over emphasized. In Nigeria, most of the studies were based on gross pathological examination at the abattoir (Igbokwe et al., 2001; Ameen et al., 2008; Aliyu et al., 2009; Ibironke and Fasina, 2010; Kwaghe et al., 2011) due to poor research infrastructure, funding and man power. There is paucity of information on bovine tuberculosis in Yola, Adamawa State, this study is therefore aimed at providing baseline information on the prevalence and seasonal variation of gross pathological lesions associated with bovine tuberculosis in cattle slaughtered in abattoirs in Yola, Adamawa State, Nigeria.

\section{MATERIALS AND METHODS}

Adamawa State is located at the North Eastern part of Nigeria (Figure 1). It lies between latitude 7 and $110^{\circ}$ $\mathrm{N}$ and between Longitude 11 and $140^{\circ}$ E. It shares boundary with Taraba State in the south and west, Gombe State in its North-west and Borno State to the North. The State has an international boundary with the Cameroon Republic along its eastern side. It has a land area of about $38,741 \mathrm{~km}^{2}$ (Adebayo, 1999). The State is divided into 21 local government areas. Adamawa State has a tropical wet and dry climate. Dry season lasts for a minimum of five months (November- March) while the wet season spans April to October. Mean annual rainfall in the State ranges from $700 \mathrm{~mm}$ in the Northwest, to $1600 \mathrm{~mm}$ in the extreme southern part of the State (Adebayo, 1999). The State has low humidity and high temperature. The climate is also characterized by high evapo-transpiration especially during the dry season (Adebayo, 1999). Yola, the State capital being an urban centre has an estimated population of about 200,000 people.

\section{Data collection}

Abattoir data were collected, after a formal permission obtained from relevant authority at the Ministry of Agriculture and Natural Resources (MANR) Yola, Adamawa state.

Meat inspections at abattoirs in Yola were carried out by qualified veterinarians who served as meat inspectors. Data collected include; number of cattle slaughtered monthly, number of cattle slaughtered that exhibit gross pathological lesions typical of bovine tuberculosis and their sex. These data were collected for a period of five (5) years $(2008$ - 2012). Post mortem examination of the carcass was done by meticulous visual examination, careful palpation and incision of the lungs, kidney, liver, lymph nodes, spleen, heart, and other part of the tissues/ organs of the body for condemnation. Affected parts are usually trimmed and the rest passed for consumption while generalized cases of bovine tuberculosis are usually seized and destroyed by the veterinarians (FAO, 1993). No pre slaughter test or ante mortem examination was carried out before slaughter.

\section{Data analysis}

Prevalence was calculated as the number of cattle with suspected bovine tuberculosis lesions divided by the number of cattle examined at post mortem within the specified period (Aliyu et al., 2009). Data obtained were further subjected to student t-test and ANOVA for the establishment of significance using SPSS version 16. 


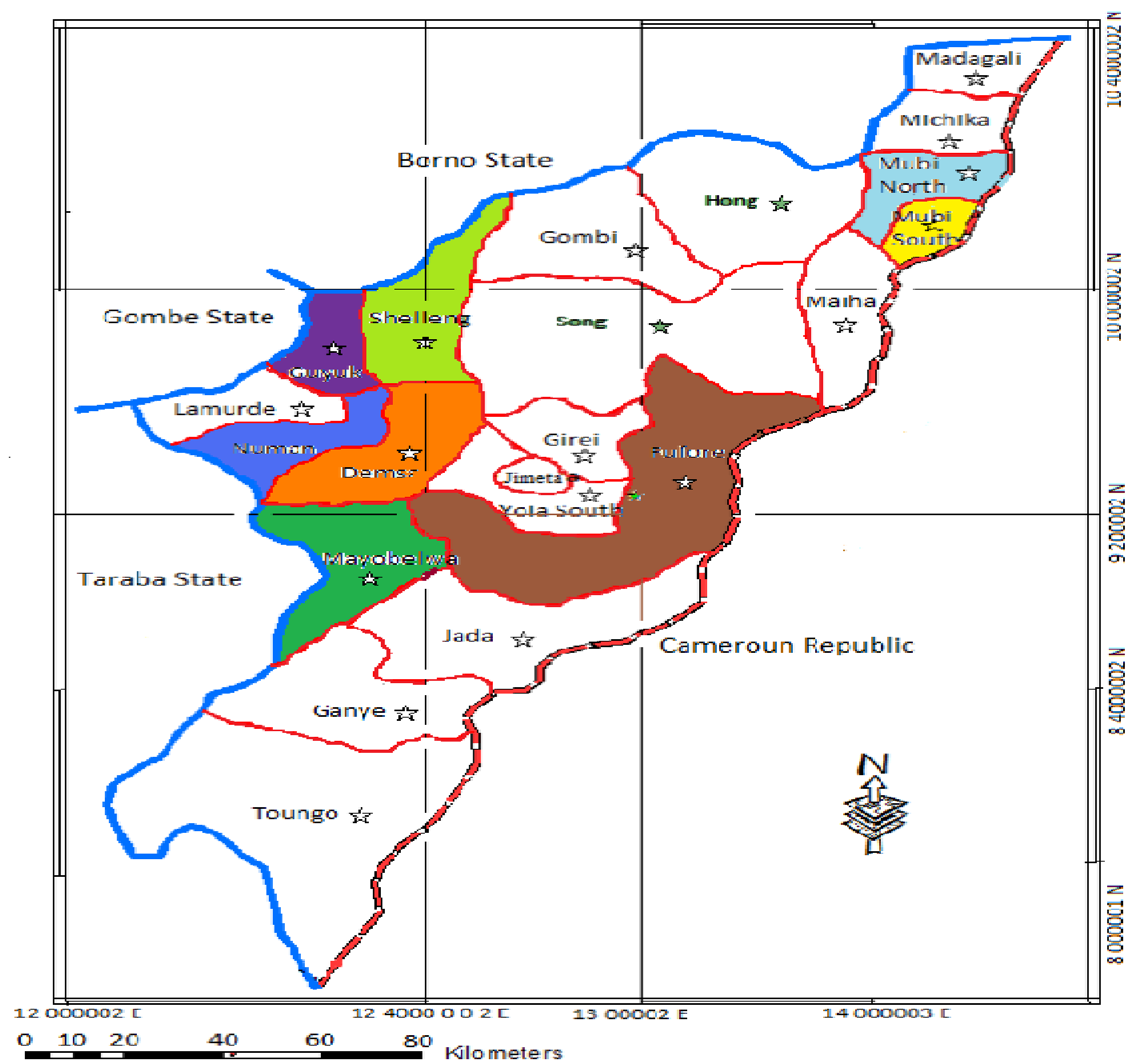

Figure 1: Map of Adamawa State showing Yola

\section{RESULTS}

\section{Annual distribution}

Table 1 show meat inspection data for the number of slaughtered cattle and bovine tuberculosis lesions detection for a period of five years (January 2008 to December 2012). In 2008 a total of 16753 (22.62\%) cattle were slaughtered, similar figure were slaughtered in 2009 but from 2010 to 2012 the number of cattle slaughtered in the abattoirs decreases drastically to $13152(17.75 \%)$, there was a significant difference between the number of cattle slaughtered from 2008, 20009 and 2011 and from 2010 and 2012 (p > 0.05). Annual distribution of detection of tuberculosis lesions in cattle slaughtered in Yola show that the highest prevalence of TB lesions were detected in 2011 with a mean detection of $12.73 \%$ (95\% CI: $8.2184-17.2499 \%)$ and is significantly different from the mean detection recorded in $2008(8.68 \%) 2009(7.30 \%)$ and $2010(4.40 \%)(\mathrm{p}<0.05)$. An overall mean detection of $8.78 \%$ (95\% CI: $7.5698-9.9852 \%)$ was recorded for the period of five years (Table 1 and Figure 2). 


\section{E. F. Ejeh and others}

\section{Sasonal variation}

A total of 74079 cattle were slaughtered at the Yola abattoir from 2008 to 2012, during the late raining season more cattle were slaughtered 26170 (35.33\%) than other season, although this figure is not significantly different compare to total number slaughtered during other seasons.

While total number of cattle slaughtered $11640(12.71 \%)$ during the late dry season is lower compare to other seasons, also they were not different statistically $(\mathrm{p}>0.05)$. The prevalence of tuberculous lesions among cattle slaughtered in Yola from early raining season to late dry season ranges from $10.62 \%$ (95\% CI: 8.06 - 13.18 ) to $12.71 \%$ (95\% CI: 7.70 - 17.73). Prevalence of tuberculous lesions recorded during the late dry season $(12.71 \%)$ is higher compare to other seasons and is significantly different from the prevalence of tuberculous lesions recorded during the late raining season and early dry season $(\mathrm{P}<0.05)$. The lowest prevalence was recorded during the late raining season $6.98 \%$ (95\% CI: $5.46-8.50 \%)$ and early dry season $6.71 \%(95 \%$ CI: 5.71 $7.71 \%$ ).

Table 1. Number of cattle slaughtered and prevalence of bovine tuberculous lesions detected in Yola abattoirs from $2008-2012$

\begin{tabular}{|lccc|}
\hline Year & No. Slaughtered $(\%)$ & No. with TB lesions & Prevalence \% $(95 \%$ CI $)$ \\
\hline 2008 & $16753(22.62)^{\mathrm{a}}$ & 1303 & $7.7^{\mathrm{c}}(7.4-8.2)$ \\
2009 & $16394(22.13)^{\mathrm{a}}$ & 1147 & $6.9^{\mathrm{c}}(6.6-7.4)$ \\
2010 & $13590(18.35)^{\mathrm{b}}$ & 671 & $4.9^{\mathrm{d}}(4.6-5.3)$ \\
2011 & $14290(19.29)^{\mathrm{a}}$ & 2088 & $14.6^{\mathrm{e}}(14.0-15.2)$ \\
2012 & $13152(17.75)^{\mathrm{b}}$ & 1403 & $10.7^{\mathrm{g}}(10.1-11.2)$ \\
Season & & & \\
Early Rain & $18235(24.62)$ & 1997 & $10.9^{\mathrm{a}}(10.5-11.4)$ \\
Late Rain & $26170(35.33)$ & 1931 & $7.4^{\mathrm{b}}(7.1-7.7)$ \\
Early Dry & $18033(24.34)$ & 1242 & $6.9^{\mathrm{b}}(6.5-7.3)$ \\
Late Dry & $11640(12.71)$ & 1422 & $12.2^{\mathrm{c}}(11.6-12.8)$ \\
Sex & & & \\
Male & $29629(40.00)^{\mathrm{c}}$ & 2205 & $7.4^{\mathrm{a}}(7.1-7.7)$ \\
Female & $44450(60.00)^{\mathrm{d}}$ & 6612 & $9.9^{\mathrm{b}}(9.6-10.2)$ \\
\hline Total & $74079(100.00)$ & & $8.7-9.1)$ \\
\hline
\end{tabular}

Mean percentages with the different letter(s) in the same column were different significantly $(\mathrm{p}>0.05)$

\section{Sexual distribution}

The sexual distribution of bovine tuberculous lesions in cattle slaughtered in Yola from 2008 to 2012 is presented in Table 1. More female cattle were slaughtered $44450(60.0 \%)$ than male cattle, there was statistical significant difference between male and female cattle slaughtered in Yola, Adamawa state $(\mathrm{p}<0.05)$. Also the prevalence of tuberculous lesion in female cattle slaughtered in Yola $(10.99 \%(-5.62422-0.90845 \%)$ is significantly different from the prevalence of tuberculous lesions recorded in male cattle slaughtered in abattoirs in Yola $(\mathrm{p}<0.05)$. 
Monthly pattern of distribution of bovine tuberculosis.

The prevalence was high from January, during the late dry season and then increases from February and peaks in March which coincided with the driest and hottest month in Yola, it then drop in April.

The prevalence of tuberculous lesions gradually peaks again in June and August and decreases more gradually from August to December (Figure 2).

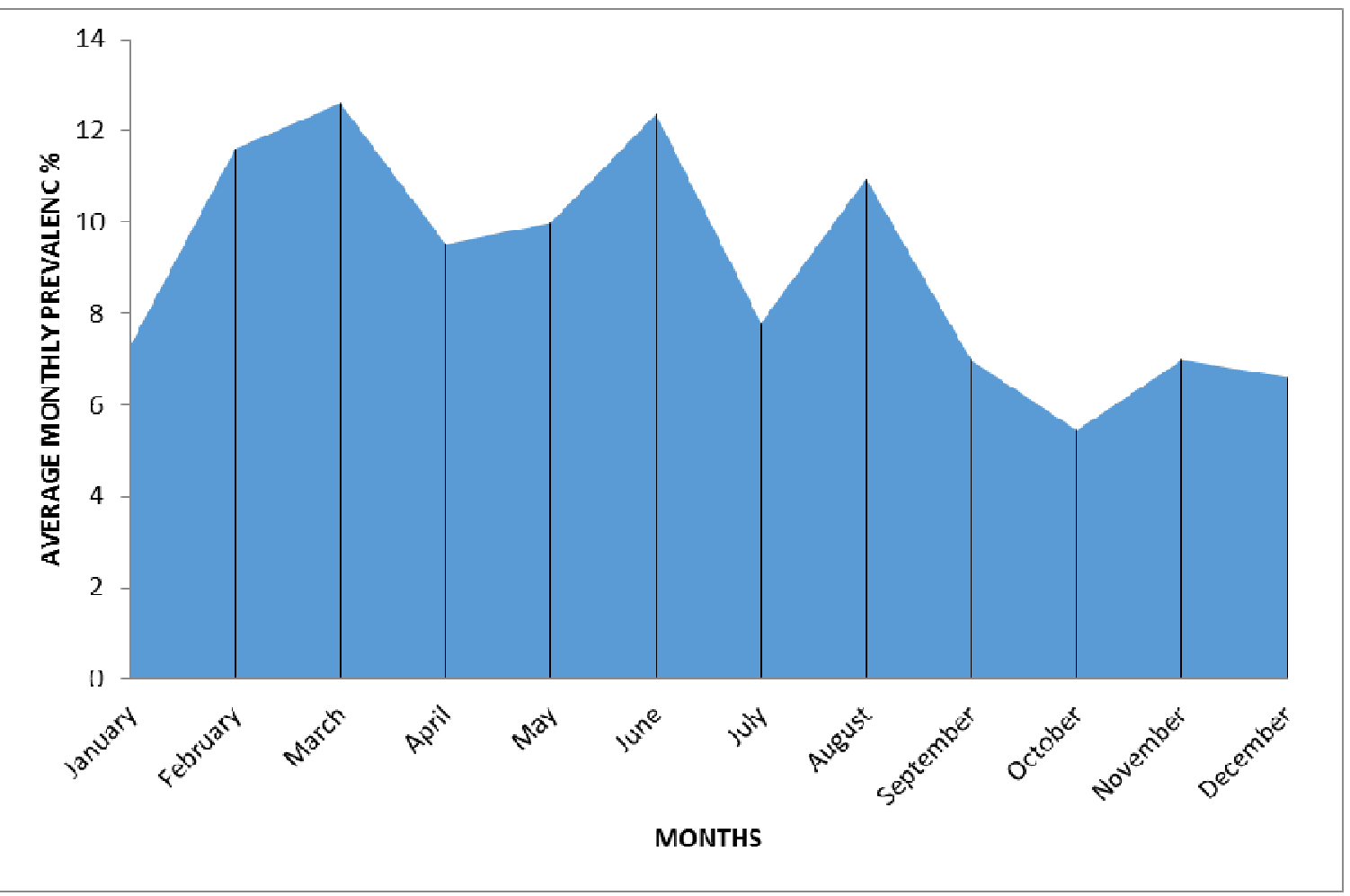

Figure 2: Show the pattern of distribution of the average monthly prevalence of tuberculous lesions in cattle slaughtered in abattoirs in Yola.

\section{DISCUSSION}

The uses of secondary data to determine the prevalence of bovine tuberculosis is not a novel finding per se but it provide information in the overall context of disease surveillance and monitoring (Cassidy et al., 2008; Aliyu et al., 2009). In developing countries especially Nigeria where laboratory investigations are not been carried out at the abattoirs due to lack of laboratory infrastructures and implementation of Government policy, abattoir meat inspection for pathological lesions remain the best option for monitoring bovine tuberculosis and other important disease prevalence (Aliyu et al., 2009). The annual prevalence of tuberculous lesions in cattle slaughtered at the Yola abattoirs from 2008 to 2012 range from $8.68 \%(-11.33 \%)$ in 2008 to $10.33 \%(6.63-12.03 \%)$ in 2012 with an overall annual prevalence of bovine tuberculosis lesions of $8.78 \%(7.57-9.99 \%)$. Similar prevalence $(8.30 \%)$ was reported by Cadmus et al., (2003) in food Animals in Nigeria. These findings are higher than earlier reports of bovine tuberculosis in the area. In Adamawa a prevalence of $0.34 \%$ was reported by Aliyu et al., (2009) and other parts of Nigeria such as Ogbomoso, 0.55\% (Ameen et al., 2008), 1.4\% in Enugu (Nwata et al., 2011) except in Gombe State where the prevalence of bovine tubercululous lesions recorded in abattoirs was $12.27 \%$ (Aliyu et al., 2009). Researchers in other parts of African countries reported similar findings. In Chad a prevalence of about $9 \%$ bovine TB was reported in slaughtered cattle (Milan et al., 2000), and 6\% prevalence in Cameron (Theon, 2009). 


\section{E. F. Ejeh and others}

The reason for the high prevalence of tuberculous lesions in cattle slaughtered in Yola abattoirs is not clear but may be due to the fact that there is no active bovine tuberculosis control program in Nigeria and that movement of cattle across both local and international boundaries, this situation may promote the entrance of infected animals from neighboring countries such as Chad, Republic of Niger and Cameron (Aliyu et al., 2009), another explanation for the high prevalence of tuberculous lesions in cattle slaughtered in Yola abattoirs could be due to absence of pre- slaughter examination and or test to separate cattle that are fit for slaughter from those that are not fit for slaughter. Season play significant role in the detection of bovine tuberculous lesions in cattle slaughtered in Yola abattoirs.

During the late dry season and early raining season, prevalence of tuberculous lesions were $12.71 \%$ and $10.62 \%$ while the prevalence was lower during late rainy season $(6.98 \%)$ and early dry season $(6.71 \%)$ respectively. This findings differ from the report of Awah - Ndukum et al. (2010) in Cameron who reported that the detection of TB lesions was not influenced by season but was high during stressful periods such as inter season and peak - season periods. Also Ameen et al. (2008) reported similar finding in Oshogbo, Nigeria. Nwata et al. (2011) reported a prevalence of $13.2 \%$ during the rainy season and $12.5 \%$ during the dry season, which showed that variation in seasonal prevalence was not significant. Although these researchers do not consider the influence of various stages of the seasons such as early and late season on tuberculosis lesions detection. However, Bikom and Oboegbulem (2007) reported a strong association between tuberculous lesions and seasonal distribution. In a similar study in Egypt, Ahmed et al. (2013) reported significant difference between season and pathological finding in cattle slaughtered in Ismailia abattoir. The reason for the difference in seasonal variation and tuberculous detection observed in this study is yet unknown. There was strong association between sex and tuberculous lesions detected in cattle slaughtered in Yola abattoirs. These findings agree with that of Nwata et al. (2011) and Awah - Ndukum et al. (2010). Ameen et al. (2008) reported that there was no strong association between sex and tuberculous lesions detected in slaughtered cattle. Female cattle stay longer in the herd than male cattle for breeding purpose making them more exposed to Mycobacterium spp. (Milan et al., 2000; Ita et al., 2005; Nwata et al., 2011).

\section{CONCLUSION}

The result of this study indicates that bovine tuberculosis is endemic in cattle slaughtered in Yola abattoirs meant for human consumption, therefore human are at risk of acquiring tuberculosis through consumption of contaminated meat. Further studies should be carried out to investigate the species of Mycobacterium responsible for the lesions recorded in abattoirs in Yola. Study is also needed in humans who are at risk of zoonotic tuberculosis especially immunocompromised individuals, livestock rarer, abattoir workers, meat vendors and animal health professionals to determine the epidemiology of zoonotic tuberculosis. There is need for veterinarians to intensify effort to educate those who are involved in the meat industry on the danger of zoonoses especially tuberculosis.

\section{ACKNOWLEDGMENTS}

The authors which to acknowledge the assistant of the veterinarians at the in Yola for allowing the collection of abattoir data used in this publication. They also express their gratitude to the director of veterinary services, Ministry of Agriculture and Natural Resources (MANR), Yola for his cooperation and assistant.

\section{REFERENCES}

1. Adebayo AA (1999). Climate I: Sunshine,Temperature, Evaporation and Relative humidity in Adebayo, A. A. \& Tukur, A. L. (Eds) Adamawa State In Maps.Geography Department, Fedearal University of Technology, Yola. Paraclette Publishers, Yola. Pp 20-22.

2. Ahmed AM, Ismail SAS and Dessouki AA (2013). Pathological lesions survey and economic loss for male cattle slaughtered at Ismailia abattoir. International Food Research Journal 20(2): 857-863.

3. Aliyu MMJ, Adamu YJ, Bilyaminu YA (2009). Current Prevalence of Tuberculous Lesions among Slaughtered Cattle in Northeastern States of Nigeria. Revue d'Elevage et de Medecine Veterinaire des Pays Tropicaux 62 (1): 13-16.

4. Amanfu W (2006). The situation of tuberculosis and tuberculosis control in animals of economic interest. Tuberculosis 86: 330-335. 
5. Ameen SA, Adedeji OS, Raheem AK, Leigh OO, Rafiu TA, and Ige AO (2008). Current Status of Bovine Tuberculosis in Ogbomoso Area of Oyo State. Middle-East Journal of Scientific Research 3 (4): 207-210.

6. Anonymous (2009). Bovine tuberculosis. Manual of diagnostic tests and vaccines for terrestrial animals: Office International des Epizooties (OIE).

7. Anonymous (2013). Michigan Department of Natural Resources. Wildlife Disease. Bovine Tuberculosis. $<$ http://www.michigan.gov/dnr/0,1607,7-153-10370_12150_12220-99064--,00.html> (Accessed July, 2013).

8. Awah-Ndukum J, Kudi AC, Bradley G, Ane-Anyangwe IN, Fon-Tebug S, Tchoumboue J (2010). Prevalence of bovine tuberculosis in abattoirs of the Littoral and Western highland regions of Cameroon: A cause for public health concern. Veterinary Medicine International; doi:10.4061/2010/495015.

9. Ayele WY, Neill SD, Zinsstag J, Weiss MG and Pavlik I (2004). Bovine tuberculosis: An old disease but a new threat to Africa. International Journal of Tuberculosis and Lung Disease 8: 924-937.

10. Bikom PM and Oboegbulem SI (2007). Prevalence of suspected tuberculosis lesions in cattle slaughtered in cross river state abattoirs. Nigerian journal of animal production 34 (2): $301-305$.

11. Brosch R, Gordon SV, Marmiesse M, Brodin P, Buchrieser C, Eiglmeier K, Garnier T, Gutierrez C, Hewinson G, Kremer K, Persons LM, Pym AS, Samper S, van Soolingen D, and Cole ST (2002). A new evolutionary scenario for the Mycobacterium tuberculosiscomplex. Proceeding of the National Academy of Sciences USA 99: 3684-3689.

12. Cadmus S, Palmer S, Melissa O, James D, Karen G (2006). Molecular Analysis of Human and Bovine Tubercle Bacilli from a Local Setting in Nigeria. Journal of Clinical Microbiology 44: 29-34.

13. Cadmus SI, Yakubu MK, Magaji AA (2010). Mycobacteriumbovis, but also $M$ africanum present in raw milk of pastoral cattle in north-central Nigeria. Tropical Animal Health Production 42: 1047-1048.

14. Cassidy JP, Bryson DG, Pollock JM, Evans RT, Forster F and Neill SD (1998). Early lesion formation in cattle experimentally infected with Mycobacterium bovis. Journal of Comparative Pathology 119: 27-44.

15. Cosivi O, Grange JM, Daborn CJ, Ravijglione MC, Fujikura T, Cousins D (1998). Zoonotic tuberculosis due to Mycobacterium bovis in developing countries. Emerging Infectious Diseases 4: 59-70.

16. FAO (1994). A manual for the primary animal health care worker. Food and Agriculture Organization of the United Nations, Rome.

17. Ibironke AA and Fasina FO (2010). Socio-economic implications of bovine liver rejection in a major abattoir in south-western Nigeria. Revista de CiênciasAgrárias 33 (2) 211 - 216.

18. Igbokwe IO, Madaki IY, Danburam S, Ameh JA, Aliyu MM, Nwosu CO (2001). Prevalence of pulmonary tuberculous lesions in cattle slaughtered in abattoirs in North-Eastern Nigeria. Revue d'Elevage et de Medecine Veterinaire des Pays Tropicaux 54: 191-194.

19. Ita AY and Udofia SM (2005). Epidemiology and endemicity of pulmonary tuberculosis in southeastern Nigeria. Southeast Asian journal of tropical medicine and public health 36(2): 317 - 323.

20. Jenkins AO, Cadmus SIB, Venter EH, Pourcel C, Haure Y, Vergnaud C and Godfroid J (2011). Molecular epidemiology of human and animal tuberculosis in Ibadan, Southwestern Nigeria. Veterinary Microbiology 151: $139-147$.

21. Kaneene JB and Thoen CO (2004). Tuberculosis. Journal American Veterinary Medical Association 224(5): $685-691$.

22. Kumar A, Deshane JS, Crossman DK, Bolisetty S, Yan B, Kramnik I, Agarwal A and Steyn AKC. Heme Oxygenase-1-derived Carbon Monoxide Induces the Mycobacterium tuberculosis Dormancy Regulon. Journal of Biology and Chemistry 283(26): 18032-18039.

23. Kwaghe AY, Ameh JA, Ambali A, Gararawa JT, Bukar G and Jauro U (2011). A Retrospective Study on Bovine and Human Tuberculosis Cases in Maiduguri, Borno State. Researcher 3(4): 39 - 43.

24. Liebana E, Johnson L, Gough J, Durr P, Jahans K, Clifton-Hadley R, Spencer Y, Hewinson RG and Downs SH (2008). Pathology of naturally occurring bovine tuberculosis in England and Wales. The Veterinary Journal 176: 354-360.

25. Michel AL, Muller B, Van Helden PD (2010). Mycobacterium bovis at the animal-human interface: a problem, or not? Veterinary Microbiology 140: 371-381.

26. Milan, F., Sanchez, M., Toledo, P., Ramirez, C., and Saltillan M. A. (2000). Descriptive study of bovine and human TB in Queretaro, Mexico. Review of Latinoamerican Microbiology 42(1): 13 - 19. 


\section{E. F. Ejeh and others}

27. Nwata JA, Umeononigwe CN, Abonyi GE and Onunkwo JI (2011). Retrospective study of bovine and human tuberculosis in abattoirs and hospitals in Enugu State, Southeast Nigeria. Journal of public health and epidemiology, 3(7): $329-336$.

28. Rohonczy BE, Balachandran VB, Dukes WT, Payeur BJ, Rhyan CJ, Saari AD, Whiting LT, Wilson HS and Jarnagin LJ (1996). A Comparison of Gross Pathology, Histopathology, and Mycobacterial Culture for the Diagnosis of Tuberculosis in Elk (Cervus elaphus). Canadian Journal of Veterinary Research 60: 108-114.

29. Smith NH, Gordon SV, de la Rua-Domenech R, Clifton-Hadley RS, Hewinson RG (2006). Bottlenecks and broomsticks: the molecular evolution of Mycobacterium bovis. National Review of Microbiology 4: 670 681.

30. Thoen CO, Lobue P and De Kantor I (2006). The importance of Mycobacterium bovis as a zoonosis. Veterinary Microbiology 112: 339-345.

31. Thoen CO, Lobue P, Enarson DA, Kaneene JB and De Kantor IN (2009). Tuberculosis: A re-emerging disease of animals and humans. Veterinaria Italiana 45: 135-181.

32. Tweddle NE and Livingstone P (1994). Bovine tuberculosis control and eradication programs in Australia and New Zealand. Veterinary Microbiology 40: 23-39.

33. Vekemans M, Cartoux M, Diagbouga S, Dembele M, Kone B, Delafosse A (1999). Potential source of human exposure to Mycobacterium bovis in Burkina Faso, in the context of the HIV epidemic. Clinical Microbiology and Infection 5: 617-621.

34. Wentink GH, Frankena K, Bosch JC, Vandehoek JED, van den Berg TH (2000). Prevention of disease transmission by semen in cattle. Livestock Production Science 62: 207-220.

35. WHO (2006). The Control of Neglected Zoonotic Diseases. A route to poverty allevation. Geneva, World Health Organization. Ref Type: Report.

36. World Health Organization: Who report (2009). Global tuberculosis control, surveillance, planning, financing. Available at: http://www.who.int/tb/publications/global_report/2009/pdf/full_report.pdf. 